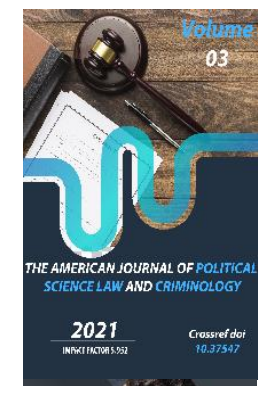

\title{
Think Tanks In The Formation Of The Central Asian Vector Of British Foreign Policy
}

Shakhnoza Akramjanovna Azimbayeva

Doctoral Student Of University Of World Economy And Diplomacy, Uzbekistan

Journal Website:

http://theamericanjour nals.com/index.php/taj psic

Copyright: Original content from this work may be used under the terms of the creative commons attributes 4.0 licence.

\section{ABSTRACT}

This article examines the role and place of British think tanks in the design and development of the country's foreign policy towards the Central Asian region. This issue is studied in combination with an analysis of the history of the formation of British think tanks, the positions of these centers in relation to Central Asia in the early 9os of the twentieth century after the collapse of the USSR and the state of modern think tanks that study Central Asia and their influence on the decision-making process in Great Britain.

\section{KEYWORDS}

UK, think tanks, foreign policy, decision making, foreign affairs bodies, academia.

\section{INTRODUCTION}

Political decision-making has always been and remains a process of complex measures with the involvement of the public and a wide range of experts, scientists and politicians. Today, in many developed countries, such unique institutions of analytics as think tanks are the most important link in not only the study of a particular situation or phenomenon, but also in the development of a foreign policy course. The UK is one of the pioneers in institutional strengthening the relationship between external relations bodies and think tanks.Despite the well-studiedness of British think tanks from different political, socioeconomic and historical frameworks, the question of how they influenced the formation of the modern Central Asian vector of British foreign policy remains one of the least studied in science. At first glance, this may seem to be the result of the lack of 
interest of British expert circles in the region or the low degree of importance of Central Asia for the country's entire foreign policy. However, even if one simply takes into account the UK's global politics and the geopolitical significance of Central Asia, the assertion of the UK's disinterest in Central Asia becomes unlikely. This fact justifies the relevance of studying the role of Great Britain's analytical centers in the development of its foreign policy towards our region.

\section{METHODS OF ANALYSIS}

Methods of both theoretical and empirical analysis were used while writing this article. In particular, from theoretical methods, a systematic approach was used to consider the issue under study as a system; the method of deduction according to the principle "from the general to the particular" - in the study of think tanks of Central Asian studies within the framework of the general system of British think tanks; also methods of classification when the question under study is grouped according to certain characteristics and abstraction to study a specific property of the issues of research. From empirical methods, the method of comparative analysis was used to compare two or more research objects.

\section{THE RESULTS OF RESEARCH}

Before going directly to the revise of modern think tanks in the UK that study Central Asia and to some extent influence decision-making, we need to pay attention to the history of the formation of the institution of a think tank in the UK in order to find out the general characteristics, methods of work and the mechanism of interaction of these centers with state structures of the country.
Thus, Great Britain, as a recent global superpower and the largest empire in the world, more than anyone else needed a constant study of its colonies and the degree of work of state structures in these vast lands. This need in the 19th century influenced the creation of the world's first think tank, the British Royal United Services Institute, which still exists and bears the name already as Royal United Services Institute for Defence and Security Studies (RUSI). Since 1831, the institute began to study the state of public service in the colonies and abroad, especially on security and intelligence services, on the basis of constant analytical and scientific activities [1]. The peculiarity of this first think tank from the academic scientific community, which in Great Britain was very developed and had great potential, but did not depend on the State and were considered as an independent system, was that the think tank depended on the state and worked for it. However it was also independent in making research and elaborating results.

It should be noted that during the Great Game, when there was a geopolitical rivalry between the British and Russian empires for dominance in South and Central Asia in the 19th - early 20th centuries, it was this center that played an important role in the study of Central Asia and solving personnel issues for military and civil intelligence, and in making research groups on the discovery of region. In addition, this institute on an ongoing basis studied the issues of the military expansion of the Russian Empire and its expansion to the south [8]. That means that the first analytical centers of UK were already interconnected with Central Asia. 
In 1884 a "Fabian Society" was founded there which is a much more real prototype of modern "think tanks" as they were a nonprofit independent organization [2]. "Think tanks" in UK have gone through a fairly long period of transformation and development, during which the nature of their work changed depending on the requests for research and analytical activities in various spheres of the life of the state and society [3, p.107].

Gradually, think tanks have naturally become involved more actively in the domestic politics of Great Britain. For example, the Fabian Society has become a think tank in the Labor Party. "Policy Exchanges" and "Reforms" became more conservative. There also appeared centers studying purely international relations and foreign policy as The Policy Studies Institute.

In the last quarter of the twentieth century, the term a think tank in Britain was synonymous with a specific "policy planning and analytical research unit" that existed within the central government. However, in the 80 s of 20 century this term acquired a completely different meaning and became applicable to the external (in relation to the government), ideological and market organizations that made up the electorate of Margaret Thatcher, who sought to shift public policy towards "a different concept of political economy and social policy" [4].

Nowadays, British think tanks, as well as American ones, range from research institutes to ideological groups; Moreover, ideological, party groups in both countries began to appear mainly after 1945. Despite the difference in the style of work and priorities, all British think tanks have broadly similar goals and common ways of achieving them. It should be noted that there are two main goals to which all think tanks strive with varying degrees of intensity [5]. The first is influencing the opinion of the establishment; the second is providing information for making current decisions in the field of public policy [6].

Regarding the question of how UK think tanks influenced the formation of the country's state strategic vision in relation to the newly independent states of Central Asia, it should be noted that they played three main key roles:

- Conducting academic research, creating ideological structures and helping to form a clearer understanding of key political and economic issues in the national interests of Great Britain in Central Asia. Such research, along with purely academic circles, was carried out by such think tanks as the Caucasus and Central Asian Security Studies (the center has been transformed and today works within the framework of the programs of the St. Andrews Institute), Bow group, Center for Policy Studies, Chatham House, Foreign policy center, etc.

- Conducting political consulting, analyzing the political situation, developing effective practical solutions in relation to Central Asia. For example, the Central Asian Institute for Strategic Studies was organizing the interaction of Central Asian experts and scholars with British experts for a deeper understanding of Central Asia and its problems, as well as needs so that Great Britain could develop its most optimal foreign policy for the region. Activities in this direction were not based 
on long-term studies that took a long time, but based on shorter and faster analytical materials. Also, these think tanks actively interacted with the media, politicians, business, formed the agenda for Central Asia, helped countries such as Kazakhstan and Kyrgyzstan to promote their image in the UK.

- Development of the ideological basis for Great Britain's policy in Central Asia. To answer the question of what it should be aimed at investment, economic modernization, or should it focus on human rights. Political reforms and democracy. Think tanks such as Demos, Politeia and Reforms have defined the ideological framework - they have become issues of administrative and political reforms and assistance in the democratization of Central Asia.

Since the 2000s, economic research think tanks and hybrid think tanks have been active in the region with many founders from different countries, including Central Asia. Most of these centers were located in Kyrgyzstan. And since the late 2010s, British legal and financial think tanks began to show their interest in the region. If Kazakhstan became their first destination, then after political changes Uzbekistan also arouses their interest. For example, since 2020, the Center for Economic Research and Reforms (CEIR) under the Administration of the President of the Republic of Uzbekistan began to cooperate with the PRISM analytical center in London (UK), which specializes in financial issues [7].

\section{CONCLUSION}

In conclusion, it can be noted that think tanks are a stronghold of independent expertise and diagnostics for the country with a minimum of costs, saving state resources and personnel. They balance the expenses of government bureaucracy and make public policy based on more fundamental and well-researched empirical knowledge. It is thanks to them that foreign policy becomes more long-term, institutional and less impacted by human factor.

British foreign policy towards Central Asia, despite the fact that it has historical roots from the Great Game in the region in the 19 century, helped their country to re-discover and interpret Central Asia and its new 5 countries after their independence. They played not only the role of researchers, but also consultants, image makers, ideologists, and a target group to resolve the issue of interaction between British and Central Asian experts.

If we take into account that the UK itself is in transformation after Brexit process, then there is the likelihood of some rethinking of its foreign policy towards our region in the medium term, and British think tanks will need a more diverse and detailed analysis of Central Asia than the initial general and strategic one, which defined the more anticipatory nature of the United Kingdom's foreign policy in the region.

\section{REFERENCES}

1. Damian P O'Connor. Between Peace and War: British Defence and the Royal United Services Institute, 18312010. RUSI. 2011, P. 356; 
2. Stone D. The British Think Tank

Tradition. Available at: http://www.nira.or.jp/past/publ/review /97summer/sto.htm (accessed at: 13.06.2021).

3. Баринова Е.А. «Мозговые центры» Великобритании: история, типология и значение// жур. Выношу на защиту. -2015.- №6. - С. 107-109;

4. Приписнова Е.С. О некоторых проблемах определения $и$ деятельности мозговых центров в Великобритании // Genesis: исторические исследования. - 2016. № 2. -С. $56-62$;

5. David M Ricci. The Transformation of American Politics. New Haven: Yale University Press, 1993. P.21.

6. William Wallace. Between Two Worlds: Think Tanks and Foreign Policy. // C. Hill and P. Beshoff (eds.), Two Worlds of International Relations. London: Routledge and LSE, 1994. P. 141.

7. Мозговые центры Узбекистана и Британии расширяют сотрудничество. 23.12.2019. Available at:

https://www.cer.uz/ru/news/news/mo zgovye-centry-uzbekistana-i-britaniirasshiryayut-sotrudnichestvo (accessed: 14.06.2021).

8. Mohl Raymond A. Confrontation in Central Asia, 1885"// History Today, March 1969, Vol. 19 Issue 3, P. 176-183. 